\title{
The Development of Supplementary Textbooks Based on Local Wisdom with Inquiry Learning Model in Elementary School
}

\author{
Evi Seftiana M. Thoha B. S. Jaya Alben Ambarita Darsono \\ Faculty of Teacher Training and Education, University of Lampung \\ Jln. Soemantri Brojonegoro No.1 GedungMeneng Bandar Lampung Indonesia
}

\begin{abstract}
This research and development aims to develop teaching suplement books based on local wisdom with inquiry learning models to improve student learning outcomes, and the effectiveness of textbooks. Research and development (R \& D) refers to the theory of Borg and Gall. The subjects of this study is experts in material validation, media, teachers, and fourth grade students of Public Elementary School 2 Pasuruan, Penengahan, South Lampung Regency. The instrument that used was a test to measure student learning outcomes and a questionnaire to measure the feasibility of textbooks. This final product is a textbooks that has been validated by material experts, media experts, and classroom teachers. The results showed that the textbook developed based on the results of the analysis of student needs and could be used in the curriculum2013, it was attractive to students seen from the positive student response, and effective for learning seen from the improvement in learning outcomes.
\end{abstract}

Keywords: Textbooks, Local Wisdom, Inquiry, Learning Outcomes

DOI: $10.7176 / \mathrm{JEP} / 10-3-13$

\section{Introduction}

Education is a conscious and planned effort to create a learning atmosphere and learning process so that students actively develop their potential to have religious spiritual strength, self-control, personality, intelligence, noble character, and skills needed by themselves, society, nation and country.

So far, only one or two books that have been used in most schools. Moreover, in the curriculum 2013, the government provided the same textbook to apply to all schools at every level, both in cities and in villages, both in Java and outside Java. The use of limited learning resources that view the content of learning from one point of view has the potential to make learning less meaningful, not even the possibility of learning material that has no relevance to the real life of students.

Teaching materials are part of the learning media. According to Riyana (2009: 7), learning media always consists of two important elements, that are the elements of equipment or hardware (hardware) and the elements of the message element inside (message / software). The textbooks are one of the learning media that can be one of the learning resources of students. Through combining with the right learning model, the use of textbooks that elevate the local wisdom of a region as a learning companion is expected to improve students' abilities.

There are four preferred learning models in the curriculum2013, one of which is the inquiry learning model. Inquiry learning model is a teaching procedure that emphasizes the activities of students independently to find scientific concepts, especially on historical subjects that require understanding and mastery of scientific thinking. This learning model will lead the students more actively doing and researching in and outside the classroom with the guidance of the teacher.

The inquiry process according to Sagala in Sudjarwo (2012: 221) are, (1) observation (observation), (2) asking (questioning), (3) submitting a guess (hypothesis), (4) data gathering (data gathering), (5 ) conclussion. This inquiry learning model is considered suitable to be united with local wisdom-based learning that has been increasingly not used anymore by most people.

The local wisdom (local wisdom) transformation is an attempt to pass on the local cultural wealth in the form of values and norms that apply in the local area. The transparency of local cultural wisdom is often interrupted in certain generations due to various problems. The shift in values is one reason for a culture to be abandoned, sophisticated communication technology also influences the thinking of people who tend to look for cultures that come from other nations and risk leaving their own culture that is considered outdated or contrary to outside culture. When the wisdom of local culture begins to be abandoned, in fact we have lost our identity.

Local wisdom is a term that often used by the scientists to represent systems of values and norms that are regulated, held, understood and applied by local people based on their understanding and experience in interacting and interrelating with the environment.

Learning outcomes in essence are changes in behavior after going through the teaching and learning process. According to Suprijono (2013: 7) learning outcomes are changes in behavior as a whole is not just one aspect of human potential. This means that the learning outcomes are not seen fragmented or separate, but comprehensive.

Therefore, the alternatives used to improve student learning outcomes are (1) Producing local wisdom based on the textbooks with inquiry learning models for fourth grade students of Public Elementary School 2 Pasuruan 
(2) Knowing the effectiveness of local wisdom-based on the textbooks with inquiry learning models that can improve learning outcomes of fourth grade students of Public Elementary School 2 Pasuruan.

\section{Method}

The research method that used is Research and Development (Research and Development). The steps used refer to the theory of Borg \& Gall (1983: 781) which consists of 10 steps of development while still referring to the research and development (R \& D) model by Borg and Gall (1983: 781) the researchers will only take steps one through the seventh step, that are the research step and initial information collection until the final product revision.

The population in the study were fourth grade students (four) in Public Elementary Schools in Penengahan, South Lampung Regency, which consisted of 33 elementary schools and MI. Determination of the sample using Purposive sampling technique is a technique of determining the sample if as many as 60 students in Public Elementary School 2 Pasuruan.

The data collection stage in this development was obtained from filling out questionnaires by teachers and students. Questionnaires are used to obtain data on expert tests, small group trials, large group tests, attractiveness tests. In the expert validation stage, data was obtained from filling out the questionnaire with material testing by expert lecturers. The effectiveness of the use of textbooks was obtained from the pretest and posttest given to students in fourth grade class A of Public Elementary School 2 Pasuruan before and after using textbooks.

The effectiveness of the use of textbookswas analyzed using validity, reliability, power difference, difficulty level and normalized n-gain value analysis.

\section{Results And Discussion}

\subsection{Research result}

The results of this research and development is local wisdom-based textbookswith inquiry learning models. The material developed is the theme 5 of my hero, the sub-four theme of the struggle of the fourth grade Elementary School heroes. The results of each stage of the development procedure are carried out as follows.

\subsubsection{Collection of Initial Information}

The initial stage of this research was carried out by identifying the learning process and collecting learning outcomes documents in fourth grade of Elementary School Gugus Anggrek in Pasuruan, South Lampung Regency. The results of the preliminary research are used as a consideration and the basis for the development of local wisdom-based on textbooks with inquiry learning models whose development must be based on empirical data about the profiles and subjects studied.

Based on the results of the needs questionnaire analysis in August 2018 in the fourth grade of Islamic Elementery School Miftahul Huda, Public Elementery School 2 Pasuruan, and Public Elementery School 3 Pasuruan. The initial data were obtained as follows: Learning patterns tend to be conventional, that are learning more applying teacher centered approaches, student learning outcomes in social studies classified as low, textbooks that are used have not introduced local culture and cultural heritage that exist to students. Textbooks that are used by educators only contain the culture of a particular region, not including the culture of the area where the student lives.

Based on the results of the preliminary research, it is necessary to develop textbooks to overcome existing problems so that students can actively engage and be able to introduce local culture and cultural heritage of Lampung. The developed textbook is a local wisdom-based on supplementary textbook with an inquiry learning model that is able to improve student learning outcomes.

\subsubsection{Planning}

Planning the development of supplementary textbooks based on local wisdomwith inquiry learning model is carried out by steps a) curriculum analysis, b) preparation of the Local Wisdom Based on Supplementary Book framework with Inquiry Learning Model, c) systematic determination, and d) planning evaluation tools.

3.1.3 The development of textbook products

This stage is a follow-up of the design at the planning stage, Preparation of Textbooks on Local Wisdom-Based on Supplements with Learning Models Inquiry is based on aspects of content and presentation.

3.1.4 Test the initial product

The initial product trial was conducted by validating textbooks on material and media/design aspects, as well as validating usability by fourth grade teachers. Expert Validation also gives advice and input to the Supplementary Textbook Based on Local Wisdom with Inquiry Learning Model and repairs are carried out according to recommendations for improvement of product validation results.

Suggestions and input from material experts include: improvement of learning objectives, arrangement of activities adjusted to the stages of inquiry, include sources in the image. Validator media expert suggested: The picture on the cover page was replaced with the Lampung hero, and replaced the brighter image and color. 


\subsubsection{Initial Product Revision}

Product revisions are based on suggestions given by the validator. Researchers make revisions as suggested.

3.1.6 Small group trials

Small group trials were conducted in fourth grade class B of Public Elementary School 2 Pasuruan, Penengahan, South Lampung Regency. Small group research involved 10 people consisting of 3 people with low initial abilities, 4 people with moderate initial abilities, and 3 people with high initial abilities. This small group trial was conducted to determine the effectiveness of textbooks in improving student learning outcomes.

\subsubsection{Product Revision}

Based on the results of testing of supplementary textbooks based on local wisdomwith inquiry learning model in small groups the results of an increase in student learning outcomes were obtained. Then supplementary books based on local wisdom with this inquiry learning model were not revised, and were feasible to be tested in large groups.

\subsubsection{Large Group Field Test / Test}

The subjects of the large group trial were fourth grade class A students of Public Elementary School 2 Pasuruan, Penengahan, South Lampung Regency, which totaled 33 students which were held on November 4 - November 11 2018. Before carrying out the first learning, students did the pretest. After attending the study using supplementary textbooks based on local wisdom with the inquiry learning model until the sixth meeting, students did posttest. It is intended to find out the effectiveness of supplementary textbooks based on local wisdom with the inquiry learning model by looking at whether or not there is an increase in learning outcomes before and after learning using supplementary textbooks based on local wisdom with inquiry learning model.

\subsubsection{Final Product Revision}

The final product revision is based on the results of hypothesis testing and findings in the field when the product is tested. Based on a large group trial, the student learning outcomes are increased. Furthermore, based on the results of validation consultations, material experts, media experts, and practitioners became a reference in making conclusions that supplementary textbooks based on local wisdom with inquiry learning model was not revised and were feasible to implement.

\subsection{The Effectiveness Test of the Textbooks}

The effectiveness of textbooks can be seen from the improvement of student learning outcomes before and after using a supplementary textbook based on local wisdomwith inquiry learning models. Increased learning outcomes between pretest and posttest were analyzed using $\mathrm{N}$-gain with calculation results of 0.51 (medium category). Based on these calculations, the hypothesis is accepted that is "supplementary textbooks based on local wisdom with an effective inquiry learning model to improve student learning outcomes".

\section{Discussion}

\subsection{Product Development of Supplementary Textbooks Based on Local Wisdom with Inquiry Learning Model}

The products of supplementary textbooks based on local wisdom with inquiry learning model that developed have met the concepts of learning. Based on the foundation of constructive learning theory, learning is the result of students' construction as a result of their interaction with the environment. This is in accordance with the opinion of Susanto (2014: 96) that learning according to constructivism theory is that students must find themselves and transform complex information, check new information with old rules, and revise it if the rules no longer apply. Therefore, the development of supplementary textbooks based on local wisdom with inquiry learning model is designed. So that students can observe, experience themselves, and obtain information that available in the textbooks in the form of text, images, illustrations, or steps of activities, thus encouraging students to construct knowledge with their own experience.

Although the quantity of material developed in supplementary textbooks based on local wisdom with inquiry learning model in the study only took one basic competency and two lessons, it still did not reduce the value that supplementary textbooks based on local wisdom with inquiry learning modelwas one of the alternative material innovations good teaching and can be used in learning. Supplementary textbooks based on local wisdom with inquiry learning modelis suitable to be used as a reference and companion for developing the subject matter contained in the student bookin curriculum 2013, because this textbook was designed and developed in reference to the thematic bookin curriculum 2013 .

\subsection{The effectiveness of Suplementary Textbooks Based on Local Wisdom with Inquiry Learning Models}

The effectiveness of supplementary textbooks based on local wisdom with inquiry learning model is seen from the learning outcomes obtained by students before and after using supplementary textbooks based on local wisdom with inquiry learning model. The effectiveness test is carried out by learning outcomes tests designed and assessed based on student learning outcomes. The effectiveness test is analyzed using N-gain. The results of the N-gain calculation are 0.51 (moderate category), this indicates an increase between learning outcomes before 
and after using a supplementary textbook based on local wisdom with inquiry learning models. The results of the study indicate that supplementary books based on local wisdom with inquiry learning models can improve student learning outcomes.

\section{Conclusion}

The development research conclusions are that the products produced in this study are supplementary textbookproducts based on local wisdom with inquiry learning models developed that are feasible to use based on the results of the validation of material experts and media experts; supplementary textbooks based on local wisdom with inquiry learning model is effectively used in the learning process for foruth grade class A students of Public Elementary Shool 2 Pasuruan, Penengahan, South Lampung Regency to improve learning outcomes.

\section{References}

Borg \& Gall. 1983. Educational Research: An Introduction (4 th ed). Longman Inc: New York \& London. Riyana, Cepi. 2009. Media Pembelajaran. Dirjen Pendais Kemenag RI. Jakarta.

Sudjarwo.Basrowi.2012. Mengenal Model Pembelajaran. Jenggala Pustaka Utama. Surabaya.

Suprijono, Agus. 2013. Coorperative Learning Teori dan Aplikasi PAIKEM. Pustaka Belajar: Yogyakarta. 